\title{
Determination of Affecting Factors on Profitability of Banking Sector: An Examination upon the Turkish Banking Sector for the Period of 2006-2018
}

\author{
Bankacılık Sektöründe Karlılığı Etkileyen Faktörlerin Belirlenmesi: Türk Bankacılık \\ Sektörünün 2006-2018 Dönemi Üzerine Bir İnceleme
}

Mustafa Tevfik KARTAL*

$\ddot{O} Z$

Türk Bankacılık Sektörü'nün (TBS) net karı 2018 yılında 54,1 milyar TL’ye ulaşmasına karşın sektörün karlılı̆g bir süredir azalmaktadır. 2006 yılında \%2,3 olan aktif karlılığ 2018 yılında \%1,4'e gerilemiştir. Benzer şekilde, 2006 yılında $\% 18,8$ olan özkaynak karlılı̆̆ 2018 yılında \%10,50’ye gerilemiştir. Bu rakamlar, karlılıktaki düşüş ĕgilimini doğrulamaktadır. Bu ĕgilim bankaların kredi verme kapasitini sınarladı̆̆ için risk oluşturmaktadır. Bu nedenle, TBS'nin karlılık seviyesi önem taşımaktadır. Karlılık seviyesinin sürdürülebilirliğini salğamak için öncelikle karlılı̆̆ etkileyen faktörler belirlenmelidir. Bu kapsamda, Çok Değişkenli Uyumlu Regresyon Uzanımları (MARS) yöntemi, 11 açıklayıcı değişken ve 2006-2018 dönemindeki üç aylık veriler kullanılmıştır. Net karın, kredilerin, sermayenin, sorunlu krediler/toplam krediler oranının, toplam aktiflerin ve USD/TL döviz kurunun Türkiye'de bankacılık sektörünün karlılı̆̆ını etkilediği belirlenmiştir. Düzenleyici otoriteler tarafindan karlıliğın sürdürülebilirliğinin să̆lanmasına ve mevcut seviyesinden yukarı çekilmesine yönelik tedbirler alınmalıdır. Böylece, bankalar finansman ve ekonomik büyümenin desteklenmesine yönelik daha fazla kredi sağlanması imkânına kavuşacaklardır.

ANAHTAR KELIMELER

Bankacılık Sektörü, Karlıkı, Etkili Faktörler, MARS, Türkiye

\begin{abstract}
Although net profit of Turkish Banking Sector (TBS) has reached TL 54.1 billion in 2018, the profitability of TBS has been decreasing. Return on assets of TBS has decreased from $2.3 \%$ in 2006 to 1.4\% in 2018. Similarly, return of equity of TBS has decreased from 18.8\% in 2006 to $10.50 \%$ in 2018. This figures verify the decreasing trend in profitability. This trend presents risks for limiting of providing credits of banks. Therefore, the level of profitability of TBS has importance. Affecting factors on profitability should be detected first in order to keep profitability stable. In this context, Multivariate Adaptive Regression Splines (MARS) method, 11 explanatory variables, and quarterly data are used between 2006 and 2018. It is determined that net profits, credits, capital, nonperforming loans (NPL)/total credits, total assets, and USD/TL foreign exchange rate (FER) affect the profitability of banking sector in Turkey. Necessary measures should be taken by regulatory authorities to keep net profit stable and increase the profitability of the sector from the current level. Hence, banks could have the opportunity to provide much more credits for financing and supporting economic growth.
\end{abstract}

KEYWORDS

Banking Sector, Profitability, Affecting Factors, MARS, Turkey

\begin{tabular}{|c|c|c|}
\hline & $\begin{array}{c}\text { Makale Gelis Tarihi / Submission Date } \\
18.09 .2019\end{array}$ & $\begin{array}{c}\text { Makale Kabul Tarihi / Date of Acceptance } \\
\text { O1.12.2020 }\end{array}$ \\
\hline Attf & \multicolumn{2}{|c|}{$\begin{array}{l}\text { Kartal, M. T. (2021). Determination of Affecting Factors on Profitability of Banking Sector: An Examination upon } \\
\text { the Turkish Banking Sector for the Period of 2006-2018. Selçuk Üniversitesi Sosyal Bilimler Meslek Yüksekokulu } \\
\text { Dergisi, } 24 \text { (1), 1-14. }\end{array}$} \\
\hline
\end{tabular}

* Assoc. Prof. Dr. in Banking, Borsa İstanbul Financial Reporting and Subsidiaries Directorate, Turkey, mustafatevfikkartal@gmail.com, ORCID: 0000-0001-8038-8241. 


\section{INTRODUCTION}

Each country has a financial system which can be divided into two groups generally as the bank-based and the market-based system. Most of the countries, including Turkey, have a bank-based financial system which means that most of the funding sources to the economic actors are provided from banks (Kartal et al., 2018). For this reason, banks are important in such countries.

The banking sector is one of the sectors which are regulated highly and strictly by the states and the governments because banks have so much importance for the countries and developments in banking sectors have potential to affect the financial systems and macro economies of countries (Kar et al., 2008). In other words, there is too much legislation regulating banking sectors and banks.

In Turkey, Banking Law (BL) numbered 5411 regulates Turkish Banking Sector (TBS) strictly. Moreover, Banking Regulation and Supervision Agency (BRSA) has made a variety of secondary regulation on TBS with the authorization of BL (Kartal \& Çoban Çelikdemir, 2019). In addition to BRSA, also other regulatory bodies such as Ministry of Commerce, Capital Markets Board (only for publicly held banks), and the Central Bank of the Central Bank of the Republic of Turkey make secondary regulation on TBS.

One of the most important issues is profitability in terms of banks to sustain their activities in a healthy way. Sustainability in activities of banks results in profitability (Demirgüç-Kunt \& Huizinga, 1999). There are so many indicators showing the development trend of the sector such as return on assets (ROA), return on equity (ROE), and net interest margin (NIM) which are the most basic profitability indicators.

The development of the profitability of the banking sector is monitored by shareholders and regulatory bodies. Unfortunately, hard times like economic crises have a negative effect on the profitability of the banks. In these times, ROA and ROE decline at an important amount. For example, ROA of TBS decreased from $3.41 \%$ in 2007 to $2.54 \%$ in 2008 with the effect of the global crisis. Similarly, ROA of TBS decreased from $24.77 \%$ in 2007 to $18.74 \%$ in 2008 (BRSA, 2019). Profitability is important from many perspectives especially increasing capital adequacy ratio (CAR) which is an important indicator followed by BRSA. Also, there is a $12 \%$ legal requirement in the indicator. Importance of the profitability is related to have an increasing effect of CAR. In order to be able to have a high CAR for TBS and Turkish banks, profitability is the only source, excluding capital increase, and it is crucial and very important for this reason.

Influential factors should be determined firstly so as to understand which factors affect the profitability of banks. For this aim, the MARS method, 11 explanatory variables, and quarterly data are used for the period of 2006/Q1-2018/Q4 to determine influential factors on CAR in Turkey. As far as it is known, the MARS method is used in only a limited number of studies for defining the profitability of the sector. So, it is thought that this study has a pioneer characteristic.

This study consists of four sections. After the introduction, Section 1 reviews the related literature upon profitability in Turkey and some other selected countries. Section 2 includes the data, methodology and research results. Section 3 summarizes the results.

\section{LITERATURE REVIEW}

The literature includes a variety of studies regarding the profitability of the banks in Turkey and other countries. Various dependent variables such as ROA, ROE, NIM and a lot of independent variables such as capital, CAR, concentration, FER, economic growth, inflation, interest rates (deposit, policy rate), market share, size, total assets, some of the ratios (NPL/total credits, total credits/total assets, total deposits/total assets) are taken into consideration in these studies.

Some studies in Turkey examined the whole banking sector while some of the others analyzed some selected banks. Büyükşalvarcı \& Abdioğlu (2011) examined TBS for the period of 2006 and 2010 via panel data analysis and concluded that ROA makes positive effects on CAR while ROE makes a negative effect. Doğan (2013) observed for the period of 2005 and 2011 via ratio analysis and stated that there is no important difference between the profitability of deposit and participation banks. Uluyol \& Ekim (2015) studied for the period of 2003 and 2013 via Johansen Cointegration Analysis and stated that there are a direct relationship deposit interest rate and profitability in the long-term. Similar to Büyükşalvarcı \& Abdioğlu (2011), Koç \& Karahan (2017) analyzed TBS for the period of 2005 and 2015 via panel data analysis and defined that ROA makes positive effects on CAR.

In addition to these studies examining whole TBS, some part of the sectors is examined in other studies in Turkey in terms of profitability by using panel data regression. Belke \& Ünal (2017) examined 23 deposit banks for the period of 2005 and 2015 via panel data regression and concluded that bank size, bank capital, liquidity risk, economic growth, inflation, policy rate, exchange rate, and market concentration affect bank profitability (ROA). Aydın (2019) analyzed 23 deposit banks for the period of 2012 and 2017 via panel data 
regression and defined that CAR is positively associated with ROA until a point, after this point it makes negative effects. Türkdönmez \& Babuşçu (2019) examined 11 deposit banks for the period of 2010 and 2017 via panel data regression and concluded that ROA is positively related with inflation, the interest rate of deposit, growth, assets quality and market share.

Besides panel data regression method, some of the studies in Turkey used panel data analysis. Alper \& Anbar (2011) examined 10 commercial banks for the period of 2002 and 2010 and concluded that size has a positive effect on ROA. Gülhan \& Uzunlar (2011) analyzed for the period of 2002 and 2010 and defined that CAR, liquidity, and size have a positive effect on ROA. Also, some macroeconomic indicators such as inflation, growth, market share, and concentration affect generally on profitability. Taşkın (2011) observed commercial banks for the period of 1995 and 2009 and stated that out of balance sheet items/total assets affects profitability positively while NPLs/total credits affects profitability negatively. Okuyan (2013) studied 23 banks for the period of 2002 and 2012 and stated CAR is positively affected by the profitability (ROA). Us (2015) examined 21 deposit banks for the period of 2002 and 2013 and concluded that FER short position has a negative effect on ROA before the crisis while it has a positive effect after the crisis. Also, size negatively affects profitability. On the other hand, ownership, growth, inflation and required reserves for FER do not affect profitability. Dizgil (2017) examined 10 biggest banks for the period of 2009 and 2017 and concluded that ROA is associated with CAR. Iş1k (2017) analyzed 3 public, 8 private and 15 foreign banks for the period of 2009 and 2016 and defined that CAR does not have a meaningful effect on ROA. Also, Afşar \& Karaçayır (2018) observed 9 banks for the period of 2002 and 2017 and stated that ROA makes positive effects on CAR.

In addition to these studies, some part of the sectors is examined in other studies in Turkey in terms of profitability by using different methods. Abbasoğlu et al. (2007) examined for the period of 2002 and 2012 via Panzar and Rosse's Approach and concluded that foreign banks have low efficiency and high profitability (ROA) concerning national banks which have high efficiency and low profitability. Ecer (2013) analyzed 11 banks for the period of 2008 and 2011 via Gray Relational Analysis and defined that asset quality is the most important determinants of profitability. Özcan \& Çiftçi (2015) observed 24 deposit banks for the period of 2006 and 2013 via econometric model and stated that there is a relationship between concentration (market share) and profitability. Yüksel (2016) examined 4 participation banks for the period of 2005 and 2015 via MARS method concluded that bank size is positively related to profitability.

In addition to studies examining the Turkish Banking Sector, the banking sector in other countries is also analyzed in some of the other studies. Short (1979) examined 60 banks in 12 developed countries for the period of 1972 and 1974 and concluded that concentration and ownership structure of banks affect profitability. Bourke (1989) examined 90 banks for the period of 1972 and 1981 and concluded that ratios of capital, liquidity, inflation, interest rate, and money supply are related to the profitability. On the other hand, there is not a relationship between profitability and ownership. Molyneux \& Thornton (1992) analyzed 18 European countries for the period of 1986 and 1989 and defined that concentration and interest rates have a positive effect on profitability (ROE). Also, there is a positive relationship between public ownership and profitability. Demirgüç-Kunt \& Huizinga (1999) examined 80 countries for the period of 1988 and 1995 and stated that profitability is associated with size, capital, leverage, and ownership.

Abreu \& Mendes (2001) studied 4 European countries for the period of 1986 and 1999 via regression and stated that high capital increases profitability. Bashir (2001) examined 8 Middle East and North Africa (MENA) countries for the period of 1993 and 1998 via panel data analysis and concluded that an increase in capital and credits affect profitability. With similar methods, Bikker \& Hu (2002) examined 26 OECD countries for the period of 1979 and 1999 and concluded that size, economic growth, and inflation have a positive effect on ROA. Williams (2003) analyzed banks in Australia for the period of 1987 and 1993 via regression and defined that market share and economic growth have a positive effect while concentration has a negative effect on profitability. Goddard et al. (2004) studied 22 European countries for the period of 1992 and 1998 via Generalized Method of Moments (GMM) method and stated that size and capital/total assets affect profitability (ROA). Pratomo \& Ismail (2006) studied 15 banks in Malaysia for the period of 1997 and 2004 via Haussman test and stated that there is an inverse relationship between capital and profitability.

Pasiouras \& Kosmidou (2007) studied 15 European countries for the period of 1995 and 2001 via regression and stated that there is a direct relationship between capital and profitability. Kosmidou \& Zopounidis (2008) examined Greece for the period of 2003 and 2004 via Promethee method and concluded that commercial banks have much more profitability. Berger et al. (2010) examined China for the period of 1996 and 2006 and concluded that foreign banks have more profitability than national banks. Hoffmann (2011) analyzed 11,777 banks in the United States of America for the period of 1995 and 2007 via GMM method and defined that 
CAR is positively associated with ROA until a point, after this point it makes negative effects. Polat \& Alkhalaf (2014) studied publicly held banks in Saudi Arabia for the period of 2008 and 2012 via panel data regression method and stated that ROA makes positive effects on CAR. Similar to this study, Aktaş et al. (2015) defined that ROA is a determinant of CAR in their study which examined 71 commercial banks in 10 countries for the period of 2007 and 2012. Also, Zarrouk et al. (2016) studied 51 banks in MENA for the period of 1994 and 2012 via GMM and stated that there is a positive relationship between economic growth and profitability.

When evaluating studies in the literature which are summarized above, it is defined that the effects of several independent variables on profitability of banks are examined and these variables have either positive or negative effects. On the other hand, determinants of profitability are the focal point of a variety of different researchers. Furthermore, they are also identified that various methodologies are used in these studies such as GMM, Gray Relational Analysis, Haussman Test, Johansen Cointegration Analysis, MARS, Panel Data Analysis, Panel Data Regression, Panzar and Rosse's Approach, Promethee, Ratio Analysis, Regression. This situation indicates that new methods could be used to identify the determinants of the profitability of banks. So, the MARS method is preferred in this study to be used because this method is highly dependable and is used intensively in the studies recently.

\section{DETERMINATION OF AFFECTING FACTORS ON PROFITABILITY OF BANKING SECTOR IN TURKEY}

\subsection{Data and Methodology}

In order to determinate which factors have an influence on the profitability of the banking sector in Turkey, the MARS method, 11 explanatory variables, and quarterly data are used for the period of 2006/Q1-2018/Q4. This period is selected by taking into consideration data availability for variables. Data regarding dependent and independent variables are gathered from BRSA (2019) and Central Bank of the Republic of Turkey (CBRT) (2019).

\subsection{MARS Method}

Friedman developed the MARS method in the 1990s. This method is a nonparametric method and one of the machine-learning methods. For this reason, there is not any restrictive assumption in the MARS method (Friedman, 1991).

There are no assumptions between dependent and independent variables in the MARS method. In founding the effects of independent variables on dependent variables, MARS uses interactions between variables, and the effects of these interactions on dependent variables (Goh et al., 2017; Liu, 2018).

MARS model is formulated as below:

$$
Y=B_{0}+\sum_{k=1}^{K} a_{n} B_{n}\left(X_{t}\right)+\varepsilon
$$

In equation (1), "Y" represents the dependent variable whereas independent variables are shown as X. On the other side, demonstrates the constant term and describes basis function. Therefore, represents the coefficient of $n$. basis functions (Friedman, 1991).

MARS method consists of two steps as follows (Sephton, 2001):

All possible models are produced by using independent variables until reaching maximum basis functions in the first step.

The best model is selected by eliminating some basis functions from the most complex model in the second step. The best model is the model that has the lowest Generalized Cross Validation (GCV) value and the highest GCVR ${ }^{2}$.

\subsection{Independent Variables}

As mentioned in the literature review section, a variety of independent variables have been used to determine which factors affect the profitability of the banking sector. Some of these variables are summarized in Table 1. 


\section{Table 1. Independent Variables}

\begin{tabular}{|c|c|}
\hline $\begin{array}{l}\text { Independent } \\
\text { Variables }\end{array}$ & References \\
\hline Capital & $\begin{array}{l}\text { Bourke (1989), Demirgüç-Kunt \& Huizinga (1999), Abreu \& Mendes (2001), Bashir (2001), } \\
\text { Pratomo \& Ismail (2006), Pasiouras \& Kosmidou (2007), Belke \& Ünal (2017) }\end{array}$ \\
\hline CAR & $\begin{array}{l}\text { Alp et al. (2010), Gülhan \& Uzunlar (2011), Jha \& Hui (2012), Güneysu et al. (2015), Tuzcu } \\
\text { (2015), Dizgil (2017), Aydın (2019), Türkdönmez \& Babuşçu (2019) }\end{array}$ \\
\hline Concentration & $\begin{array}{l}\text { Smirlock (1985), Molyneux \& Thornton (1992), Jansen \& Haan (2003), Williams (2003), Gülhan } \\
\text { \& Uzunlar (2011), Özcan \& Çiftçi (2015), Belke \& Ünal (2017) }\end{array}$ \\
\hline FER & Abreu \& Mendes (2001), Us (2015), Belke \& Ünal (2017) \\
\hline Growth & $\begin{array}{l}\text { Demirgüç-Kunt \& Huizinga (1999), Bashir (2001), Bikker \& Hu (2002), Jiang et al. (2003), } \\
\text { Williams (2003), Havrylchyk \& Jurzyk (2006), Al-Tamimi (2010), Gülhan \& Uzunlar (2011), } \\
\text { Gyamerah \& Amoah (2015), Us (2015), Zarrouk et al. (2016), Belke \& Ünal (2017), Aydın } \\
\text { (2019), Türkdönmez \& Babuşçu (2019) }\end{array}$ \\
\hline Inflation & $\begin{array}{l}\text { Bikker \& Hu (2002), Jansen \& Haan (2003), Tunay \& Silpar (2006), Gülhan \& Uzunlar (2011), } \\
\text { Belke \& Ünal (2017), Aydın (2019), Türkdönmez \& Babuşçu (2019) }\end{array}$ \\
\hline Interest Rate & $\begin{array}{l}\text { Bourke (1989), Molyneux \& Thornton (1992), Demirgüç-Kunt \& Huizinga (1999), Jansen \& } \\
\text { Haan (2003), Jiang et al. (2003), Havrylchyk \& Jurzyk (2006), Uluyol \& Ekim (2015), } \\
\text { Türkdönmez \& Babuşçu (2019) }\end{array}$ \\
\hline Market Share & $\begin{array}{l}\text { Williams (2003), Gülhan \& Uzunlar (2011), Özcan \& Çiftçi (2015), Türkdönmez \& Babuşçu } \\
\text { (2019) }\end{array}$ \\
\hline NPL/Total Credits & $\begin{array}{l}\text { Jiang et al. (2003), Samad (2004), Berger et al. (2010), Çetin \& Bitırak (2010), Gülhan \& Uzunlar } \\
\text { (2011), Taşkın (2011), Jha \& Hui (2012), Gyamerah \& Amoah (2015), Belke \& Ünal (2017), } \\
\text { Aydın (2019) }\end{array}$ \\
\hline Size & $\begin{array}{l}\text { Short (1979), Smirlock (1985), Miller \& Noulas (1997), Demirgüç-Kunt \& Huizinga (1999), } \\
\text { Bikker \& Hu (2002), Goddard et al. (2004), Tunay \& Silpar (2006), Abbasoğlu et al. (2007), Alp } \\
\text { et al. (2010), Alper \& Anbar (2011), Gülhan \& Uzunlar (2011), Us (2015), Yüksel (2016), Belke } \\
\text { \& Ünal (2017), Aydın (2019) }\end{array}$ \\
\hline Total Assets & $\begin{array}{l}\text { Bashir (2001), Goddard et al. (2004), Al-tamimi (2010), Berger et al. (2010), Gülhan \& Uzunlar } \\
\text { (2011), Jha \& Hui (2012), Williams (2003), Gyamerah \& Amoah (2015) }\end{array}$ \\
\hline $\begin{array}{l}\text { Total Credits/ } \\
\text { Total Assets }\end{array}$ & $\begin{array}{l}\text { Miller \& Noulas (1997), Demirgüç-Kunt \& Huizinga (1999), Samad \& Hassan (1999), Abreu \& } \\
\text { Mendes (2001), Bashir (2001), Jiang et al. (2003), Samad (2004), Havrylchyk \& Jurzyk (2006), } \\
\text { Kosmidou \& Zopounidis (2008), Çetin \& Bitırak (2010), Jha \& Hui (2012), Ecer (2013) }\end{array}$ \\
\hline $\begin{array}{l}\text { Total Deposits/ } \\
\text { Total Assets }\end{array}$ & $\begin{array}{l}\text { Samad \& Hassan (1999), Bashir (2001), Jiang et al. (2003), Kosmidou \& Zopounidis (2008), Jha } \\
\text { \& Hui (2012) }\end{array}$ \\
\hline
\end{tabular}

It is preferred to use ROA as the dependent variable, and capital, CAR, credits, credits/total assets, FER, interest rate, equity, net profit, NPLs, NPLs/total credits, total assets as independent variables in the study. Hence, a total of 11 variables are included in the study. Details of variables are included in Table 2.

Table 2. Details of Independent Variables

\begin{tabular}{|l|l|l|c|c|}
\hline \multicolumn{1}{|c|}{ Variables } & \multicolumn{1}{|c|}{ Abbreviation } & \multicolumn{1}{|c|}{ Description } & $\begin{array}{c}\text { Expected } \\
\text { Effects }\end{array}$ & Data Source \\
\hline Capital & CPTL & Paid in Capital & + & BDDK \\
\hline CAR & CAR & $\begin{array}{l}\text { Total Legal Equity/Total Risk Weighted } \\
\text { Assets }\end{array}$ & + & BDDK \\
\hline Credits & CRDTS & Credit Volume & + & BDDK \\
\hline
\end{tabular}




\begin{tabular}{|l|l|l|c|c|}
\hline \multicolumn{1}{|c|}{ Variables } & \multicolumn{1}{|c|}{ Abbreviation } & \multicolumn{1}{|c|}{ Description } & $\begin{array}{c}\text { Expected } \\
\text { Effects }\end{array}$ & Data Source \\
\hline $\begin{array}{l}\text { Credits/Total } \\
\text { Assets }\end{array}$ & CRDSTA & Total Credit Volume/Total Assets & + & BDDK \\
\hline FER & USDTL & USD/TL FER &,+- & TCMB \\
\hline Interest Rates & IR & $\begin{array}{l}\text { Weighted Average of Commercial Credit } \\
\text { Interest Rates }\end{array}$ & + & TCMB \\
\hline Legal Equity & EQITY & $\begin{array}{l}\text { Legal Equity } \\
\text { (Tier 1+ Tier 2-Deductions })\end{array}$ & BDDK \\
\hline Net Profit & NTPRFT & Net Profit Volume & BDDK \\
\hline NPL & NPL & $\begin{array}{l}\text { Gross NPL } \\
\text { (not deducted provisions })\end{array}$ & BDDK \\
\hline $\begin{array}{l}\text { NPL/Total } \\
\text { Credits }\end{array}$ & NPLTC & Gross NPL/Total Credit Volume & - & BDDK \\
\hline Total Assets & TA & Total Asset Volume & + \\
\hline
\end{tabular}

\subsection{Empirical Results}

\subsubsection{Descriptive Statistics}

In this study, quarterly data for the period of 2006/Q1-2018/Q4 are used. So, the number of observations is 52 and descriptive statistics are included in Table 3.

Table 3. Descriptive Statistics

\begin{tabular}{|c|c|c|c|c|c|}
\hline Variables & $\mathbf{n}$ & Min & Max & Average & Standard Deviation \\
\hline ROA $^{1,2}$ & 52 & 0.310 & 2.550 & 1.166 & 0.580 \\
\hline NTPRFT $^{3}$ & 52 & 2.750 & 54.120 & 16.715 & 11.386 \\
\hline CRDTS $^{3}$ & 52 & 171.450 & $2,587.670$ & 962.088 & 682.320 \\
\hline CPTL3 $^{2}$ & 52 & 22.200 & 96.190 & 55.563 & 20.342 \\
\hline NPLTC $^{2}$ & 52 & 2.730 & 5.640 & 3.509 & 0.744 \\
\hline TA $^{3}$ & 52 & 422.700 & $4,209.970$ & $1,611.922$ & $1,012.538$ \\
\hline CAR $^{2}$ & 52 & 14.640 & 23.090 & 17.573 & 1.893 \\
\hline USDTL $^{4}$ & 52 & 1.190 & 5.590 & 2.225 & 1.057 \\
\hline
\end{tabular}

${ }^{1}$ shows the dependent variable.

2 shows percentage.

${ }^{3}$ shows billion TL.

${ }^{4}$ shows TL.

\subsubsection{Profitability Estimation Model Findings}

In the first step of MARS analysis, all possible basis functions are produced by using 7 independent variables which affect CAR. In this process, 19 functions are produced totally which includes the best complex function. Details of 18 functions are included in Annex 1.

In the second step of MARS analysis, 14th model is determined as the best model which has the lowest GCV value and the highest GCV R2 value. Important splines between profitability and independent variables are included in Annex 2. In the best model, there are 1 constant and 15 basis functions using 7 independent variables and details of the best model are included in Table 4. 
Table 4. Profitability Basis Functions

\begin{tabular}{|c|c|c|}
\hline Basis Functions & Details & Coefficient \\
\hline & Constant & 0.964 \\
\hline $\mathrm{BF} 2$ & $\max (0,20.260$ - CAR $)$ & - \\
\hline $\mathrm{BF} 3$ & $\max (0$, NTPRFT - 14.860) & 0.051 \\
\hline $\mathrm{BF} 4$ & $\max (0,14.860$ - NTPRFT $)$ & -0.093 \\
\hline BF5 & $\max (0, \mathrm{TA}-908.620)$ & -0.000165846 \\
\hline BF6 & $\max (0,908.620$ - TA $)$ & 0.002 \\
\hline BF7 & $\max (0$, CRDTS -454.850$) * \mathrm{BF} 4$ & 0.0000492406 \\
\hline BF8 & $\max (0,454.850-\mathrm{CRDTS}) * \mathrm{BF} 4$ & -0.000466991 \\
\hline BF9 & $\max (0$, CRDTS -990.440$) * \mathrm{BF} 3$ & -0.0000170752 \\
\hline $\mathrm{BF} 10$ & $\max (0,990.440-\mathrm{CRDTS}) * \mathrm{BF} 3$ & 0.000115623 \\
\hline BF11 & $\max (0$, CPTL -62.190$)$ & -0.008 \\
\hline $\mathrm{BF} 12$ & $\max (0,62.190$ - CPTL $)$ & 0.04 \\
\hline $\mathrm{BF} 13$ & $\max (0$, NPLTC -4.440$) * \mathrm{BF} 12$ & -0.005 \\
\hline BF14 & $\max (0,4.440-\mathrm{NPLTC}) * \mathrm{BF} 12$ & -0.009 \\
\hline BF15 & $\max (0, \mathrm{TA}-3257.840) * \mathrm{BF} 2$ & 0.000082646 \\
\hline $\mathrm{BF} 17$ & $\max (0$, USDTL -1.500$) * \mathrm{BF} 6$ & -0.005 \\
\hline \multicolumn{3}{|c|}{ F Test: $3,254.329(0.000) \quad$ Adjusted $R^{2}$ : 0.999} \\
\hline
\end{tabular}

As it can be seen from Table 4, the probability value of the $\mathrm{F}$ test is 0.000 which means that the model is statistically significant. On the other hand, the explanatory value (R2) of the model is well above the acceptable limits with the value of 0.999 .

As a result of the analysis, the importance level of independent variables in terms of explanation of profitability in Turkey is included in Table 5.

Table 5. Importance Level of Independent Variables

\begin{tabular}{|c|c|c|}
\hline Variables & Importance Level & GCV \\
\hline NTPRFT & 100.000 & 0.689 \\
\hline CRDTS & 41.578 & 0.121 \\
\hline CPTL & 15.769 & 0.020 \\
\hline NPLTC & 13.287 & 0.015 \\
\hline TA & 10.463 & 0.010 \\
\hline CAR & 4.598 & 0.004 \\
\hline USDTL & 3.799 & 0.004 \\
\hline
\end{tabular}

The most important variable in terms of profitability in Turkey is net profits. Other important variables are credits, capital, NPL/total credits, total assets, CAR, and USD/TL FER respectively. On the other hand, other variables, which are included in the analysis, do not have an effect on the profitability of TBS for the period of 2006/Q1-2018/Q4.

The first effective independent variable is NTPRFT. The details of the basis functions regarding NTPRFT are included in Table 6. 
Table 6. Basis Functions of NTPRFT

\begin{tabular}{|c|l|c|}
\hline Basis Functions & \multicolumn{1}{|c|}{ Details } & Coefficient \\
\hline BF3 & $\max (0$, NTPRFT -14.860$)$ & 0.051 \\
\hline BF4 & $\max (0,14.860$ - NTPRFT $)$ & -0.093 \\
\hline
\end{tabular}

Table 6 shows that the variable takes place in 2 basis functions. BF4 has a negative coefficient $(-0.093)$. When NTPRFT is below TL 14.86 billion, then NTPRFT has a negative effect on profitability. On the other, when NTPRFT is above TL 14.86 billion because of BF3 has a positive coefficient (0.051), then NTPRFT has positive affect profitability.

The second effective independent variable is CRDTS. The details of the basis functions regarding CRDTS are included in Table 7.

Table 7. Basis Functions of CRDTS

\begin{tabular}{|c|l|c|}
\hline Basis Functions & \multicolumn{1}{|c|}{ Details } & Coefficient \\
\hline BF3 & $\max (0$, NTPRFT -14.860$)$ & 0.051 \\
\hline BF4 & $\max (0,14.860-$ NTPRFT $)$ & -0.093 \\
\hline BF7 & $\max (0$, CRDTS -454.850$) * \mathrm{BF} 4$ & 0.0000492406 \\
\hline BF8 & $\max (0,454.850-$ CRDTS $) * \mathrm{BF} 4$ & -0.000466991 \\
\hline BF9 & $\max (0$, CRDTS -990.440$) * \mathrm{BF} 3$ & -0.0000170752 \\
\hline BF10 & $\max (0,990.440-$ CRDTS $) * \mathrm{BF} 3$ & 0.000115623 \\
\hline
\end{tabular}

Table 7 shows that the variable takes place in 4 basis functions and it interacts with 2 basis function. BF10 has a positive effect if CRDTS has a value below TL 990.44 billion and NTPRFT is above of TL 14.86 billion. On the other side, BF9 gives information that this effect becomes negative when CRDTS is above TL 454.85 billion and NTPRFT is below of TL 14.86 billion.

Moreover, BF7 has a positive effect if CRDTS is between 454.85 billion and TL 990.44 billion and NTPRFT is above of TL 14.86 billion. On the other side, BF8 gives information that this effect becomes negative when CRDTS is below TL 454.85 billion and NTPRFT is below of TL 14.86 billion.

The third effective independent variable is CPTL. The details of the basis functions regarding CPTL are included in Table 8.

Table 8. Basis Functions of CPTL

\begin{tabular}{|c|l|c|}
\hline Basis Functions & \multicolumn{1}{|c|}{ Details } & Coefficient \\
\hline BF11 & $\max (0$, CPTL -62.190$)$ & -0.008 \\
\hline BF12 & $\max (0,62.190-$ CPTL $)$ & 0.040 \\
\hline
\end{tabular}

Table 8 shows that the variable takes place in 2 basis functions. BF12 has a positive effect (coefficient: 0.040) if CPTL has a value below TL 62.19 billion. On the other side, BF11 gives information that this effect becomes negative when CPTL is above of TL 62.19 billion. This is not compliant with the foreseen effect of CPTL on profitability. It was expected that when CPTL increases, profitability also increases.

The fourth effective independent variable is NPLTC. The details of the basis functions regarding NPLTC are included in Table 9.

Table 9. Basis Functions of NPLTC

\begin{tabular}{|c|l|c|}
\hline Basis Functions & \multicolumn{1}{|c|}{ Details } & Coefficient \\
\hline BF12 & $\max (0,62.190-$ CPTL $)$ & 0.040 \\
\hline BF13 & $\max (0$, NPLTC -4.440$) *$ BF12 & -0.005 \\
\hline BF14 & $\max (0,4.440-$ NPLTC $) *$ BF12 & -0.009 \\
\hline
\end{tabular}


Table 9 shows that the variable takes place in 2 basis function and it interacts with 1 basis function. BF13 has a negative effect (coefficient: -0.005) if NPLTC has a value above of $4.44 \%$ and CPTL is below of TL 62.19 billion.

The fifth effective independent variable is TA. The details of the basis functions regarding TA are included in Table 10.

Table 10. Basis Functions of TA

\begin{tabular}{|c|l|c|}
\hline Basis Functions & \multicolumn{1}{|c|}{ Details } & Coefficient \\
\hline BF2 & $\max (0,20.260-\mathrm{CAR})$ & - \\
\hline BF5 & $\max (0, \mathrm{TA}-908.620)$ & -0.000165846 \\
\hline BF6 & $\max (0,908.620-\mathrm{TA})$ & 0.002 \\
\hline BF15 & $\max (0, \mathrm{TA}-3257.840) * \mathrm{BF} 2$ & 0.000082646 \\
\hline
\end{tabular}

Table 10 shows that the variable takes place in 3 basis functions and it interacts with 1 basis function. BF6 has a positive effect (coefficient: 0.002) if TA has a value below TL 908.62 billion. Also, BF5 gives information that this effect becomes negative when TA is above of TL 908.62 billion. On the other side, BF15 has a positive effect if TA has a value above 3,257.84 billion and CAR is below TL 20.26\%.

The sixth effective independent variable is USDTL. The details of the basis functions regarding USDTL are included in Table 11.

Table 11. Basis Functions of USDTL

\begin{tabular}{|c|l|c|}
\hline Basis Functions & \multicolumn{1}{|c|}{ Details } & Coefficient \\
\hline BF6 & $\max (0,908.620-$ TA $)$ & 0.002 \\
\hline BF17 & $\max (0$, USDTL -1.500$) *$ BF6 & -0.005 \\
\hline
\end{tabular}

Table 11 shows that USDTL takes place in 1 basis function and it interacts with 1 basis function. BF17 interacts with BF6 meaning that when USDTL is above TL 1.5 and TA is above of TL 908.62 billion, then TA makes negative effects on profitability. Otherwise, TA does not affect.

The estimation model for profitability is formulated as follow as a result of the analysis:

$$
\begin{aligned}
\text { Profitability } & =0.964+0.051 * B F 3-0.093 * B F 4-0.000165846 * B F 5+0.002 \\
& * B F 6+0.0000492406 * B F 7-0.000466991 * B F 8-0.0000170752 \\
& * B F 9+.0 .000115623 * B F 10-0.008 * B F 11+0.040 * B F 12 \\
& -0.005 * B F 13-0.009 * B F 14+0.000082646 * B F 15-0.005 \\
& * B F 17
\end{aligned}
$$

\section{CONCLUSION}

Determining influential factors of profitability has importance for the health of the banking sector and financial system, and also for sustainable financial stability. The main cause underlying is that banks are the main financing source in countries including Turkey which have a bank-based financial system structure. So, making the banking system much stronger is important so that it can continue to finance economic activities. One of the basic indicators for this is profitability.

This study aimed at defining affecting factors of profitability of the banking sector in Turkey. In this context, 11 independent variables are selected by reviewing studies in the literature. Also, quarterly data for the period of 2006/Q1-2018/Q4 is gathered and analyzed by the MARS method.

As a result of the analysis, it is determined that net profits, credits, capital, nonperforming loans (NPL)/total credits, total assets, and USD/TL foreign exchange rate (FER) affect the profitability of banking sector in Turkey, respectively. According to the analysis, the most important factor is net profit. Profitability (measured with ROA in the study) decreases when total assets increase much faster than net profits. Also, TL 14.86 billion is a critical border for the effect of net profits on profitability.

Another important variable is CRDTS. It can be said that profitability decreases if CRDTS exceeds TL 990.44 billion and net profits is above of TL 14.86. The current CRDTS is around TL 2,394.43 billion and net 
profit is TL 54.12 billion in Turkey for the year 2018 end. Unfortunately, this condition causes decreases in profitability. Also, CPTL makes negative effects when it is above of TL 62.19 billion. The current CPTL is around TL 96.19 billion in Turkey for the year 2018 end. Unfortunately, this condition causes decreases in profitability and it is not compliant with the foreseen effect on profitability. It was expected that when CPTL increases, profitability also increases.

NPLTC has a negative effect on profitability when it has a value above of $4.44 \%$ and CPTL is below of TL 62.19 billion. Also, if TA has a value of above TL 3,257.840 billion, then it has a positive effect on profitability. Hopefully, it has TL 3,867.43 billion in Turkey as of 2018 end. Lastly, USD/TL FER has a negative effect on profitability when it has value above TL 1.50 and TA is below TL 908.62 billion.

With the evaluation of analysis results, it can be concluded that some negative developments in independent variables used in the study have been resulting in a negative effect on profitability. To increase profitability from the current level, which is $1.40 \%$ as of 2018 end, negative effects should be prevented in the mentioned variables. For instance, an increase in USD/TL FER should be stopped. Hence, negative effects could be prevented. Other necessary measures should be taken in other variables which have a negative effect on the profitability of the banking sector in Turkey. Hence, TBS has the opportunity in providing much more credits for supporting economic growth.

Besides this study, new studies such as examining why USD/TL FER has been increasing in Turkey could be studied and it is thought that these studies could be beneficial in making participation in the literature. Also, new statistical and econometrical methods could be used in these forthcoming studies. 


\section{REFERENCES}

Abbasoğlu, O.F., Aysan, A.F. \& Güneş, A. (2007). Concentration, Competition, Efficiency and Profitability of the Turkish Banking Sector in the Post-Crisis Period. Banks and Bank Systems, 2(3), 106-115.

Abreu, M., \& Mendes, V. (2001). Commercial Bank Interest Margins and Profitability: eVidence for Some EU Countries. In Pan-European Conference, Thessaloniki, Greece, 17-20.

Afşar, A., \& Karaçayır, E. (2018). Determinations of Capital Adequacy Ratio in Turkish Banking Sector. Anadolu University Journal of Social Sciences, 18(2), 149-160.

Aktaş, R., Açıkalın, S., Bakın, B., \& Çelik, G. (2015). The Determinants of Banks' Capital Adequacy Ratio: Some Evidence from South Eastern European Countries. Journal of Economics and Behavioral Studies, 7(1), 79-88.

Alp, A., Ban, Ü., Demirgüneş, K., \& Kılıç, S. (2010). Internal Determinants of Profitability in Turkish Banking Sector. İMKB Journal, 12, 1-15.

Alper, D. \& Anbar, A. (2011). Bank Specific and Macroeconomic Determinants of Commercial Bank Profitability: Empirical Evidence from Turkey. Business and Economics Research Journal, 2(2), 139-152.

Al-Tamimi, H., \& Hussein, A. (2010). Factors Influencing Performance of the UAE Islamic and Conventional National Banks. Global Journal of Business Research, 4(2), 1-9.

Aydın, Y. (2019). The Relationship between Bank Capital and Profitability: Evidence from Turkish Banking Sector. Journal of International Social Research, 12(62), 1174-1181.

Bashir, A. H. M. (2001). Assessing the Performance of Islamic banks: Some Evidence from the Middle East. Topics in Middle Eastern and North African, 1-11.

Belke, M., \& Ünal, E. A. (2017). Determinants of Bank Profitability: Evidence from Listed and Non-Listed Banks in Turkey. Journal of Economics Finance and Accounting, 4(4), 404-416.

Berger, A. N., Hasan, I., \& Zhou, M. (2010). The Effects of Focus versus Diversification on Bank Performance: Evidence from Chinese Banks. Journal of Banking \& Finance, 34(7), 1417-1435.

Bikker, J.A. \& Hu, H. (2002). Cyclical Patterns in Profits, Provisioning and Lending of Banks and Procyclicality of the New Basel Capital Requirements. PSL Quarterly Review, 55(221), 143-175.

Bourke, P. (1989). Concentration and Other Determinants of Bank Profitability in Europe, North America and Australia. Journal of Banking and Finance, 13, 65-79.

BRSA. (2019). Monthly Bulletin, https://www.bddk.org.tr/BultenAylik/En, 03.08.2019.

Büyükşalvarc1, A. \& Abdioğlu, H. (2011). Determinants of Capital Adequacy Ratio in Turkish Banks: A Panel Data Analysis. African Journal of Business Management, 5(27), 11199-11209.

CBRT. (2019). EVDS, https://evds2.tcmb.gov.tr, 03.08.2019.

Çetin, A. C., \& Bitırak, İ. A. (2010). Analytic Hierarchy Process Approach in Bank Performance Evaluation: An Application in the Commercial Banks and Participation Banks. Journal of Alanya Faculty of Business, 2(2), 75 92.

Demirgüç-Kunt, A., \& Huizinga, H. (1999). Determinants of Commercial Bank Interest Margins and Profitability: Some International Evidence. The World Bank Economic Review, 13(2), 379-408.

Dizgil, E. (2017). An Empirical Research on Micro Level Factors that Affect the Profitability of Deposit Banks in Turkey. Journal of BRSA Banking and Financial Markets, 11(2), 31-52.

Doğan, M. (2013). Participation and Traditional Banks Comparison of Financial Performance: The Case of Turkey. Journal of Accounting \& Finance, 58, 175-188.

Ecer, F. (2013). Comparison of Financial Performance of Private Banks in Turkey: 2008-2011 Period. Abant İzzet Baysal University Journal of Social Sciences, 13(2), 171-189.

Friedman, J. (1991). Multivariate Adaptive Regression Splines. The Annals of Statistics, 19, 1-141.

Goddard, J., Molyneux, P., \& Wilson, J. O. (2004). The Profitability of European Banks: A cross-Sectional and Dynamic Panel Analysis. The Manchester School, 72(3), 363-381.

Goh, A. T. C., Zhang, Y., Zhang, R., Zhang, W. \& Xiao, Y. (2017). Evaluating Stability of Underground Entry-Type Excavations Using Multivariate Adaptive Regression Splines and Logistic Regression. Tunnelling and Underground Space Technology, 70, 148-154.

Gülhan, Ü., \& Uzunlar, E. (2011). Factors Influencing the Bank Profitability: An Apllication on Turkish Banking Sector. Atatürk University Journal of Social Sciences Institute, 15(1), 341-368.

Güneysu, Y., Er, B., \& Ar, İ. M. (2015). AHS and GIA Methods of Performance Evaluation of Commercial Banks in Turkey with. Karadeniz Teknik University Social Sciences Institute Journal of Social Sciences, (9), 71-93.

Gyamerah, I. A., \& Amoah, B. A. B. (2015). Determinants of Bank Profitability in Ghana. International Journal of Accounting and Financial Reporting, 5(1), 173-187.

Havrylchyk, O., \& Jurzyk, E. M. (2006). Profitability of Foreign Banks in Central and Eastern Europe: Does the Entry Mode Matter? BOFIT Discussion Paper, 5, 1-42.

Hoffmann, P. Saona (2011). Determinants of the Profitability of the US Banking Industry. International Journal of Business and Social Science, 2(22), 255-269.

Işık, Ö. (2017). Internal Determinants of Profitability of State, Private And Foreign Owned Commercial Banks Operating in Turkey. Journal of Economics, Finance and Accounting, 4(3), 342-353. 
Jansen, D. \& Haan, J. (2003). Increasing Concentration in European banking: A Macro-Level Analysis. De Nederlandsche Bank Research Departmant, Research Memorandum Wo No.743.

Jha, S., \& Hui, X. (2012). A Comparison of Financial Performance of Commercial Banks: A Case Study of Nepal. African Journal of Business Management, 6(25), 7601-7611.

Jiang, G., Tang, N., Law, E., \& Sze, A. (2003). The Profitability of Banking Sector in Hong Kong. Hong Kong Monetary Authority Quarterly Bulletin, 3(36), 5-14.

Kar, M., Taş, S., \& Ağır, H. (2008). Financial System and Development in Development Economics, Editors: Sami Taban, Muhsin Kar, 2th Edition, Ekin Publications, Bursa, Turkey.

Kartal, M. T., \& Çelikdemir, N. Ç. (2019). Coordination of Internal Control and Internal Audit Activities in Banks: An Examination upon Branch Audit Activities. TIDE Academia Research, 1(1), 33-53.

Kartal, M. T., İbiş, C., \& Çatıkkaş, Ö. (2018). Adequacy of Audit Committees: A Study of Deposit Banks in Turkey. Borsa İstanbul Review, 18(2), 150-165.

Koç, Y. D., \& Karahan, F. (2017). Financial Stability Indicators of Turkish Banking Sector. International Journal of Academic Value Studies, 3(15), 148-153.

Kosmidou, K., \& Zopounidis, C. (2008). Measurement of Bank Performance in Greece. South-Eastern Europe Journal of Economics, 1(1), 79-95.

Liu, T. (2018). Multivariate Adaptive Regression Splines in Standard Cell Characterization for Nanometer Technology in Semiconductor. Chapter 3 in Topics in Splines and Applications, Edited by Young Kinh-Nhue Truong, 47-62.

Miller, S.M., \& Noulas, A.G. (1997). Portfolio Mix and Large-Bank Profitability in the USA. Applied Economics, 29, 505-512.

Molyneux, P., \& Thornton, J. (1992). Determinants of European bank profitability: A Note. Journal of Banking \& Finance, 16(6), 1173-1178.

Okuyan, H. A. (2013). Capital Structure in Turkish Banking Sector. Ege Academic Review, 13(3), 295-302.

Özcan, A., \& Çiftçi, C. (2015). Concentration and Profitability in Turkish Deposit Banking (Period in 2006-2013). Niğde Universitiy Journal of Economic and Administrative Sciences, 8(3), 1-12.

Pasiouras, F., \& Kosmidou, K. (2007). Factors Influencing the Profitability of Domestic and Foreign Commercial Banks in the European Union. Research in International Business and Finance, 21(2), 222-237.

Polat, A., \& Al-khalaf, H. (2014). What Determines Capital Adequacy in the Banking System of Kingdom of Saudi Arabia? A Panel Data Analysis on Tadawul Banks. Journal of Applied Finance and Banking, 4(5), 27-43.

Pratomo, W. A., \& Ismail, A. G. (2006). Islamic Bank Performance and Capital Structure. MPRA Paper, Paper No: 6012.

Samad, A. (2004). Performance of Interest-free Islamic Banks vis-à-vis Interest-Based Conventional Banks of Bahrain. International Journal of Economics, Management and Accounting, 12(2), 1-15.

Samad, A., \& Hassan, M. K. (1999). The Performance of Malaysian Islamic Bank during 1984-1997: An Exploratory Study. International Journal of Islamic Financial Services, 1(3), 1-14.

Sephton, P. (2001). Forecasting Recessions: Can We Do Better on MARS? Review Federal Reserve Bank of Saint Louis, 83(2), 39-49.

Short, B.K. (1979). The Relation between Commercial Bank Profit Rates and Banking Concentration in Canada, Western Europe and Japan. Journal of Banking and Finance, 3, 209-219.

Smirlock, M. (1985). Evidence on the (Non) Relationship between Concentration and Profitability in Banking. Journal of Money, Credit and Banking, 17(1), 69-83.

Taşkın, F. D. (2011). The Factors Affecting the Performance of the Turkish Commercial Banks. Ege Akademik Review, 11(2), 289-298.

Tunay, K. B., \& Silpar, A. M. (2006). Profitability Based Performance Analysis in Turkish Commercial Banking SectorI. The Banks Association of Turkey, Research Paper Series.

Tuzcu, S. (2015). The Effect of Derivatives Activty on Bank Profitability before and During the Subprime Mortgage Crisis: Evidence from Turkey. Ankara University Journal of Social Sciences, 2015, 6(1), 29-56.

Türkdönmez, C. S., \& Babuşcu, Ş. (2019). A Banking Survey to Determine the Most Effective Recovery Strategies to Prevent Customer Losses. Başkent University Journal of Commercial Sciences Faculty, 3(1), 37-54.

Uluyol, O., \& Ekim, S. (2015). A Study of The Relationship between Banking Sector's Profitability and Interest Rates on Deposits Using Johansen Cointegration and Granger Causality Test. Journal of Economics Finance and Accounting, 2(1), 58-74.

Us, V. (2015). Banking Sector Performance in Turkey Before and After the Global Crisis. The Journal of Economy, Business and Finance, 30(353), 45-74.

Williams, B. (2003). Domestic and International Determinants of Bank Profits: Foreign Banks in Australia. Journal of Banking \& Finance, 27(6), 1185-1210.

Yüksel, S. (2016). Katılım Bankalarında Karlılığı Belirleyen Faktörlerin MARS Yöntemiyle İncelenmesi. IJISEF 2016, İstanbul/Turkey.

Zarrouk, H., Daoud, K. B. J., \& Moualhi, M. (2016). Is Islamic Bank Profitability Driven by Same Forces as Conventional Banks? International Journal of Islamic and Middle Eastern Finance and Management, 9(1), 46-66. 


\section{Annexes}

Annex 1. Outputs of Profitability Estimation Model

\begin{tabular}{|c|c|c|c|}
\hline Basis Functions & Number of Total Variables & GCV & GCV R $\mathbf{R}^{2}$ \\
\hline 19 & 7 & 0.030 & 0.912 \\
\hline 18 & 7 & 0.012 & 0.966 \\
\hline 17 & 7 & 0.006 & 0.981 \\
\hline 16 & 7 & 0.004 & 0.988 \\
\hline 15 & 7 & 0.003 & 0.991 \\
\hline $14 *$ & 7 & 0.003 & 0.992 \\
\hline 13 & 7 & 0.003 & 0.991 \\
\hline 12 & 6 & 0.004 & 0.988 \\
\hline 11 & 6 & 0.005 & 0.987 \\
\hline 10 & 5 & 0.005 & 0.985 \\
\hline 9 & 5 & 0.007 & 0.981 \\
\hline 8 & 4 & 0.009 & 0.972 \\
\hline 7 & 4 & 0.013 & 0.962 \\
\hline 6 & 3 & 0.013 & 0.963 \\
\hline 5 & 3 & 0.037 & 0.893 \\
\hline 4 & 2 & 0.058 & 0.832 \\
\hline 3 & 2 & 0.105 & 0.694 \\
\hline 2 & 2 & 0.161 & 0.531 \\
\hline 1 & 1 & 0.303 & 0.118 \\
\hline
\end{tabular}

*shows the best model. 
Annex 2. Important Splines between Profitability and Independent Variables
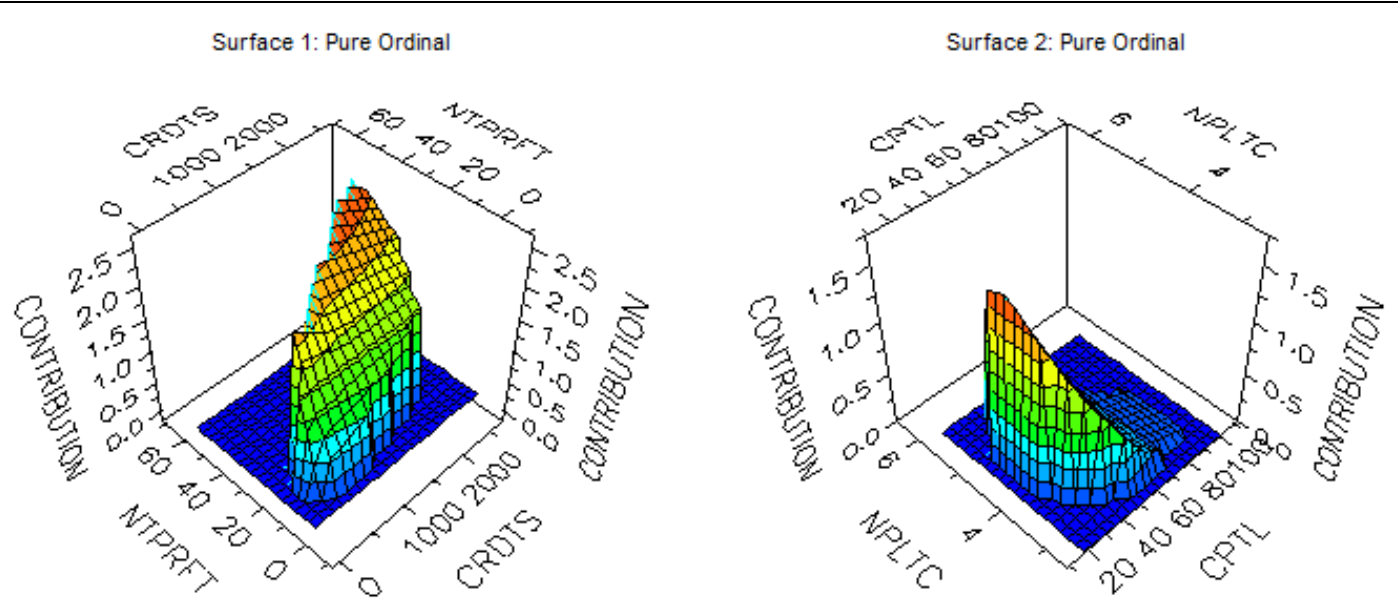

Surface 3: Pure Ordinal
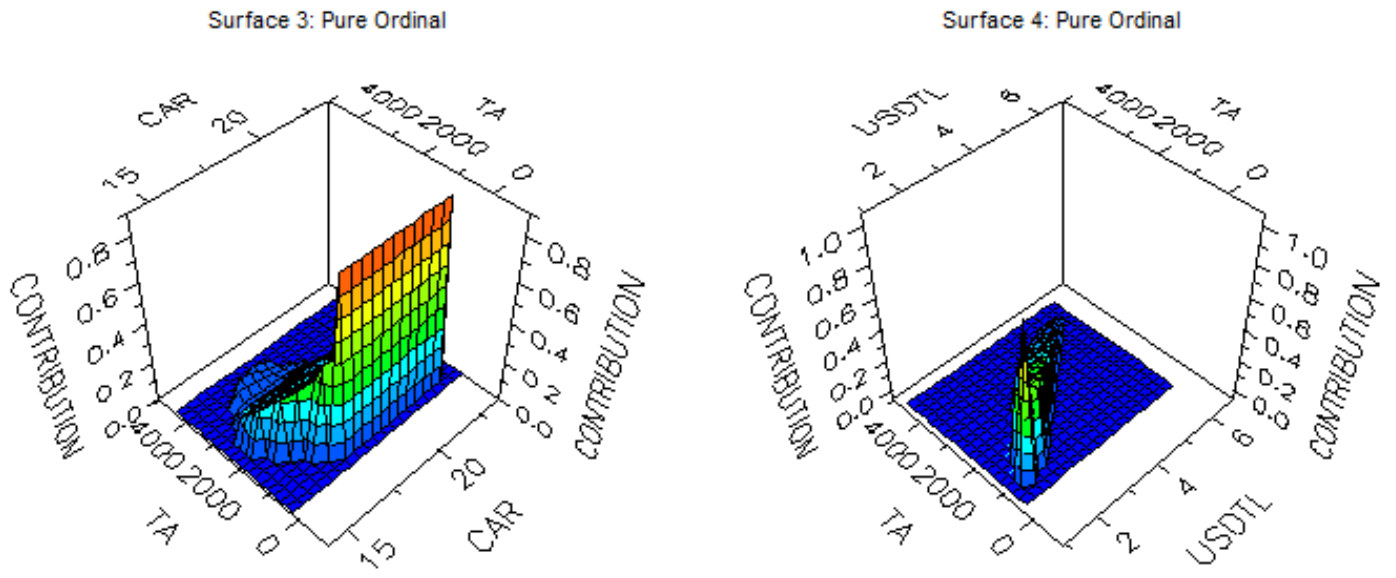

Explanation: There are mainly 4 splines. Firstly, net profit variable intereacts with the credit volume variable. Secondly, NPL/total credit ratio variable intereacts with the capital. Thirdly, total assets variable intereacts with the capital adequacy ratio. Fourthly, USD/TL FER variable intereacts with the total assets variable. 